\title{
A TÁRSADALMI RÉSZVÉTEL SZEREPE A VÁROSFEJLESZTÉS GYAKORLATÁBAN - EURÓPAI ÉS HAZAI TAPASZTALATOK
}

\author{
(The Role of Community Involvement in Urban Planning - \\ the European and the National Experience)
}

\section{FÖLDI ZSUZSA}

\begin{abstract}
Kulcsszavak:
társadalmi részvétel várostervezés IVS kritikai realizmus

A tanulmány adalékul szolgál a várostervezésben és a megưjulást célzó beavatkozásokban történö társadalmi részvétel nemzetközi és hazai szinten is tapasztalható növekvö jelentöségének magyarázatához. A vizsgált téma pontos definiálása érdekében elméleti háttérül realista modellt használ. A modell rávilágít a városi társadalom és környezete közötti hajdan organikusabb és spontán kapcsolat kiüresedésére és arra, hogy ezt miként váltja fel az esetenként alulról kezdeményezett, de többnyire felülröl irányítoit társadalmi részvétel a várostervezésben és a konkrét beavatkozásokban. A tanulmány továbbá nemzetközi és hazai példákkal szolgál a társadalmi részvétel formáira, hatékonyságára, akadályaira és törvényi szabályozására vonatkozóan. A cikk apropója a 2008-ban országosan nagy számban készüll Integrált Városfejlesztési Stratégiákhoz és Akcióterületi tervekhez kapcsolódó társadalmasitási folyamat változó megitélésủ eredményessége.
\end{abstract}

\section{Bevezetés}

Frappáns közhellyel indítva: a városi ember és lakókörnyezetének viszonya folyamatos átalakulásban van. Bármely városrész lakókörnyezetének fizikai, illetve társadalmi sajátosságait vizsgáljuk, ennek az átalakuló viszonyrendszernek a térbeli leképeződésével találkozunk. Általános tendencia, hogy a lakó- és városi környezet alapelemei (épitett környezet és a benne élő ember) közötti közvetett interakciók intenzitása erőteljesen csökken, azok érdemi tartalma erőteljesen redukálódik. A kapcsolat jellegét természetszerúleg meghatározzák az épített környezetre helyben ható közvetlen külsỏ mechanizmusok, mint pl. az önkormányzat, hatóságok, piaci szándékok; illetve a lakosság életlehetőségeire, közösségek kohéziójára, társadalmi nyitottságra is ható erők, mint a hazai és globális gazdasági, társadalmi, illetve kultúrszociológiai változások (Földi 2006) ${ }^{1}$.

A városi tér minőségi jellemzőit leginkább befolyásoló tényezők között hagyományosan mindig is jelen voltak a mikroközösségek (kisebb-nagyobb lakóközösségek). Ezek a közös élettér kapcsán hasonló érdekkel bíró csoportok képesek direkt módon, avagy különféle érdekérvényesítésre alkalmas eszközöket felhasználva (döntéshozatalban való részvétel, szélsőséges esetben akár demonstráció) lakóterületükön a történések befolyásolására. A folyamathoz persze elengedhetetlen az 
Földi Zsuzsa : A társadalmi részvétel szerepe a városfejlesztés gyakorlatában

- Európai és hazai tapasztalatok. - Tér és Társadalom 23. évf. 2009/3. 27-43. p.

ember és épített környezete között fennálló hajdan jóval organikusabb kapcsolat formalizált újrateremtése. Az utóbbi évtizedek bebizonyították, hogy erre a hagyományos demokratikus képviseleti elven történő, többszörös szürőn átmenő érdekérvényesítés messze nem elegendő és hatékony fórum. A társadalom közvetlen szerepvállalása a környezetét érintő változások előkészítésében és végrehajtásában egyszerre igényként és szükségletként merül fel.

Globális háttértendenciaként a nyugati és „,nyugatosodni kívánó” társadalmakra jellemző lassan felszámolódó helyi közösségekrỏl, társadalmi izolációról, elidegenedésről, morális válságról, közönyröl és mindezek következményeiröl már sokan, sokféle elemző tanulmányt publikáltak. Hiba lenne azonban szem elöl téveszteni a növekvő diverzifikáltságot: természetszerủleg más az általános helyzet az Egyesült Államok, Hollandia vagy Magyarország kis-, közép és nagyvárosaiban. Mindemellett növekvő különbségek mutatkoznak országonként is az egyes városokon belül. A településméret szerinti és országok közötti különbségeket erösen befolyásolja a társadalmi érettség, a demokratikus hagyományok, a részvétel szabályozottsága, a társadalmi felelösségvállalás; míg az egyes városokon belül nemzetközi tapasztalatok szerint az egyes városrészek alakításában érdekeltek szándékai mentén különbözik a viszony. Itt azonban a tapasztalatok szerint nem feltétlenül a magasabb társadalmi státusz és erősebb közösségi részvétel összefüggés a meghatározó, sőt. Bizonyos „,kiemelt státuszú létformák" egyenesen nullára redukálták a közösségi, kohézióra alapozott egészséges érdekérvényesítést, felváltva azt az egyéni érdekérvényesités különféle kifogásolható eszközeivel (ennek példáit jóval inkább hazai viszonyok között kell keresnünk). A társadalmi problémákkal erőteljesen terhelt területeken pedig a megújítást célzó komplex szociális városrehabilitációs programok irányítỏi „,mesterségesen” felülről (top-down) vonják be a helyi lakosokat a döntéshozatalba és/vagy véleménynyilvánításba (pl. Magdolna negyed, Józsefváros). Spontán, alulról építkező érdekképviseletről tehát ez esetben nincs szó, jobb esetben félúton találkozik a kettő.

Európában a városfejlesztési irányok kialakítása és a konkrét beavatkozások tervezése során a fizikai megújításon túl egyre inkább előtérbe kerül a társadalmi komponens, a változás tervezésében és kivitelezésében pedig a partnerség (társadalmi részvétel). A hazai viszonyokra jellemző, hogy a városi környezet tervezésében és alakításában történö részvétel sok esetben még formális, jelképes - miközben vannak üdító kivételek, elsősorban a helyi szinten szervezödő civil szervezeteknek köszönhetően. Cikkünk célja, hogy bemutasson néhány példát arra, hogy milyen keretek között (szabályozás és gyakorlat) müködik a városfejlesztési tevékenységet befolyásoló társadalmi részvétel egyes uniós tagállamokban, és mindezzel szembeállitsa a hazai tapasztalatokat, róvilágitson a hazai gyakorlat hiányosságaira és azok valószínüsithetö okaira.

A téma kifejtéséhez a problématerület modellezését követően röviden körüljárjuk a társadalmi részvétel szükségességének hátterében álló globális tényezőket. Ezt követően bemutatunk néhány példát a nemzetközi gyakorlatra, és ezt állítjuk szembe a hazai tapasztalatokkal. A cikk hátterében álló vizsgálat alkalmazott módszerei az absztrakció, a vonatkozó nemzetközi szakirodalom feltárása és hazai empirikus vizsgálatok ${ }^{2}$ másodelemzése. 
Földi Zsuzsa : A társadalmi részvétel szerepe a városfejlesztés gyakorlatában

- Európai és hazai tapasztalatok. - Tér és Társadalom 23. évf. 2009/3. 27-43. p.

TÉT XXIII. évf. 2009 - 3

A társadalmi részvétel szerepe...

\section{Kritikai realista elméleti keretek}

A realista absztrakció a problématerület komplexitására világít rá, és átláthatóvá teszi, hogy a városi tér és társadalom viszonyában milyen, újfajta reláció kialakulását és müködtetését indokló változások álltak be.

A kritikai realista értelmezés a vizsgált rendszert - jelen esetben a városi környezetet - alkotóelemeire bontja, vizsgálja az alkotóelemek egyedi jellemzőit és interakcióit, feltárja az interakciókat meghatározó, illetve befolyásoló mechanizmusokat, a kimenet ismeretében értékel és tesz kritikai észrevételeket a rendszeren belüli viszonyok megváltoztatására, választ adva a „Milyennek kéne lennie?”3 kritikai tudományfilozófiai alapkérdésre (Panelli 2004). Mindeközben nem téveszti szem elől, hogy dinamikus nyitott rendszerről van szó ${ }^{4}$, és a változás folyamatát tekinti központi kérdésnek (Joseph 1998), illetve, hogy a vizsgált rendszer alapjellemzőinél fogva a különféle erősségü és jellegủ hatásokra várhatóan hogyan reagál. Az alapjellemzők determinálják a változás lehetséges kimeneteit, viszont a mechanizmusok jellege és ennél fogva az alkotóelemek egymásra hatása komoly különbségeket okozhat az eredményben ${ }^{5}$.

Röviden a fentiekben foglalható össze a rendszermodellünk elméleti alapja. A városi környezetet alkotó „elemek” (azaz értelmezésünkben a társadalmi és épített környezet) egymásra hatását különbözö mechanizmusok befolyásolják, amelyeket a modell nem rendszerelemeknek, hanem rendszermüködést befolyásoló tényezőknek tekint. Ezek a tényezők és mechanizmusok évezredek (!) óta jelen vannak a városok életében, ettől lett valójában „rend”, lett szabályos, áttekinthető utcahálózat, városfal és csatorna; avagy vált müködésképtelenné egy-egy város.

A fenti „egyszerü” ember és környezet reláció plasztikusabban értelmezhetö, ha a realista modellbe beépítjük a városi környezet rétegeinek értelmezését is (1.ábra). A városi környezet több rétegre tagozódik Rapoport (1982) fogalmi rendszerében. A magot a rögzített (nagyon lassan változó) környezeti elemek jelentik, ide tartozik az épületek nagyságrendje, térbeli elhelyezkedése vagy az utcaszerkezet, Az erre „ráhúzott” második réteget a félig kötött környezeti elemek alkotják, amelyek magukban foglalják az üzleteket, a kirakatokat, az utcabútorokat, a cégéreket stb., amelyek éves, évtizedes idótávon belül változnak. Végül a nem rögzített rövid idő alatt változó környezeti elemek már leginkább a helyi társadalomhoz kötődnek: a területen élő emberek viselkedése, szokásai, kapcsolatai formálják. A rétegek együttesen minden egyes pillanatban egy rendszert alkotnak. A rétegek között kapcsolatok vannak, amelyek jellege és erőssége koronként változott, attól függően, hogy az azt befolyásoló mechanizmusok milyen szándékkal és befolyással léptek fel (néha lakóterületeket rombolva és újjaépítve, néha - mint Pest belsô történelmi lakóterületén - eszközök híján évtizedekig elhanyagolva, majd egy új gazdasági társadalmi struktúrában felértékelve). Tény, hogy az 1. ábrán halványodó nyilakkal jelzett direkt kapcsolatot a rétegek között a mechanizmusok által irányított szervezett társadalmi részvétel váltja fel. 
Földi Zsuzsa : A társadalmi részvétel szerepe a városfejlesztés gyakorlatában

- Európai és hazai tapasztalatok. - Tér és Társadalom 23. évf. 2009/3. 27-43. p.

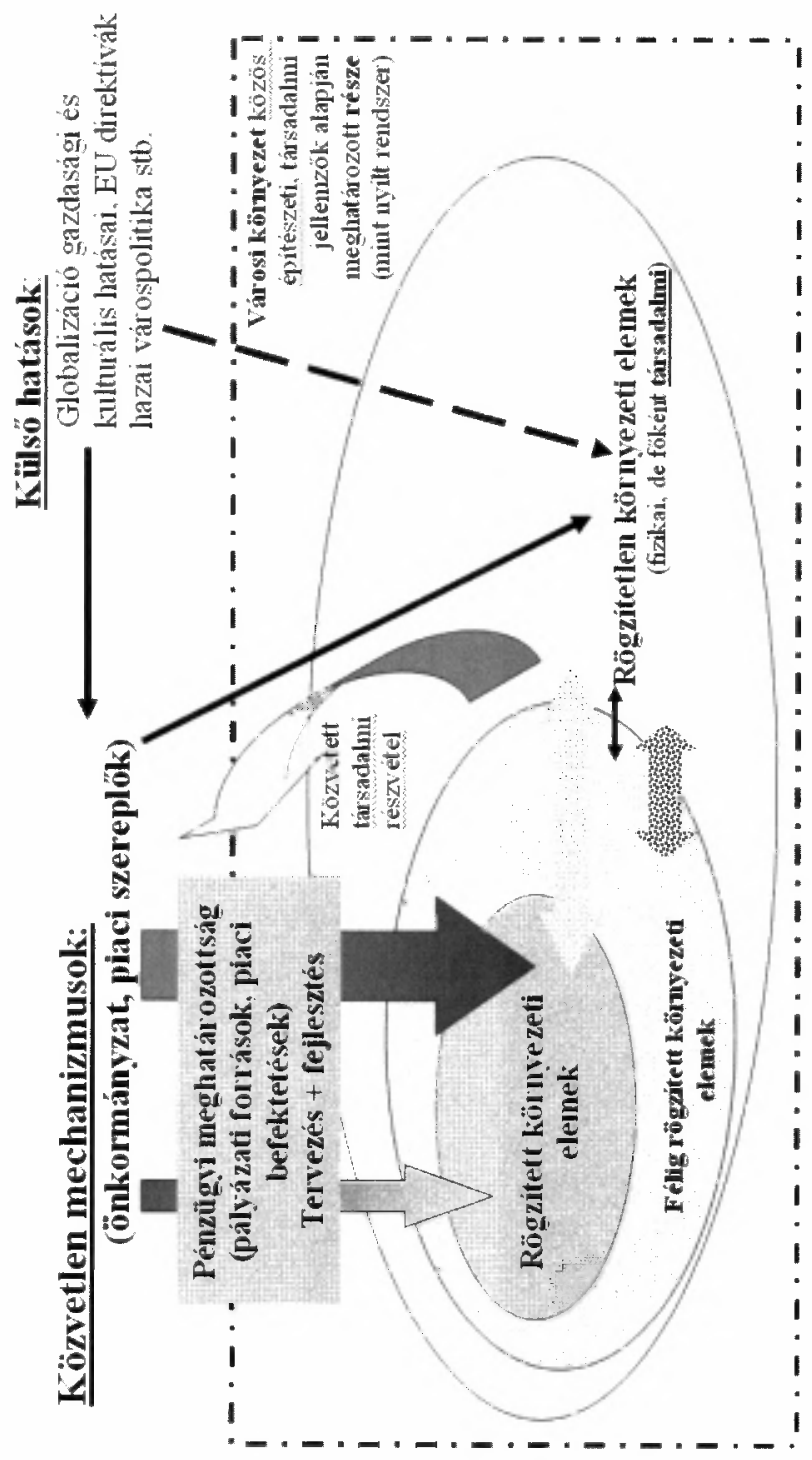

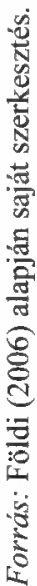


Földi Zsuzsa : A társadalmi részvétel szerepe a városfejlesztés gyakorlatában

- Európai és hazai tapasztalatok. - Tér és Társadalom 23. évf. 2009/3. 27-43. p.

Tény, hogy évszázadokon keresztül és bizonyos tekintetben a mai napig is a társadalom alapjellemzői meghatározó hatással vannak a környezet minőségére. Az adott területen élőkön és az azt használókon múlik, hogy milyen a közterületek minősége, előbb-utóbb a lakóépületekre „kiül”, hogy ki él benne. A közösségek tudatosan, vagy egyszerủen csak jelenlétükkel formálják közvetett és közvetlen környezetüket.

A mindenkori mechanizmusok (önkormányzat, piaci szereplők, hatóságok) a tervezésen, a szabályozáson és a fejlesztői tevékenységen keresztül erősen meghatározzák a kötött környezeti elemeket, ugyanakkor pl. az önkormányzat egy-egy „soft” intézkedéssel (pl. privatizáció beavatkozásai) közvetlen hatással van a rögzítetlen környezeti elemekre, azaz annak mobilitásán keresztül magára a helyi társadalomra. Ezek végül a demográfiai jellemzőkben, társadalmi összetételben képeződnek le, ami viszont kihat az épített környezet általános minőségére.

A társadalom befolyása környezetének alakulására és alakítására csak részben társadalmi tradíció kérdése, a mechanizmusok által megszabott eszközrendszer és fogadókészség eröteljesen módosítja azt. Mivel a társadalom érdemi részvételének formális keretei törvényileg nincsenek megszabva sem a helyi döntések meghozatalának, sem a tervezési dokumentumok készítésének folyamatában, a helyi társadalom esetenként eszközök híján (az egyes települési önkormányzatokban a civil kezdeményezéseknek vétó-, illetve szavazati joga nincs, csak megfigyelöként tehetnek észrevételeket) egyéb szélsőséges beavatkozásokkal él (lásd példaként a Nagymező utcai mélygarázs-építés illetve „,nemépítés” esetét ${ }^{6}$ ). Ennél valamivel kedvezőbb az általunk ,látszatrészvétel"-nek nevezett jelenség, amely többnyire az engedélyek kiadása, illetve esetleges fizikai beavatkozások megkezdése elötti pillanatban történő, következmények nélküli társadalmi jóváhagyást jelent (gyors rábólintás, letudtuk és mehet!). Többnyire jellemző azonban a társadalmi közöny, amin egyedül a közvetlen érintettség képes változtatni.

A városfejlesztést befolyásoló hosszabb távú tervezésben és döntésekben való részvétel ideálisan a dỏntés-elökészítés és a tervezés korai szakaszában (koncepció- ill. stratégiakészítés) makroszintröl (várostérség, város, városrész) indul, és egészen projektszintig terjed (felölelve ott is a tervezéstől a kivitelezésig terjedỏ lépéseket). Nemzetközi szinten ennek komoly gyakorlati tapasztalatai halmozódtak fel, de mielôtt ennek bizonyos példáit megnéznénk, a társadalmi részvétel növekvő fontosságának hátterében álló folyamatokról essen néhány szó.

\section{A társadalmi részvétel növekvö jelentöségének kiváltó okai}

A városi térben koncentráltan jelentkező társadalmi és környezeti vonatkozású problémák az európai nagyvárosokban korábban nem látott szélsőségeket érnek el a vonatkozó irodalmon túl elegendỏ az esti híradót végignézni (pl. Párizsi gettólázadás [2005], amely az EU-politikusok számára is élóvé tette a nagyvárosi problémákat ${ }^{7}$ ). Ezek megoldására a korábbi fizikai beavatkozásokon alapuló módszerek elégtelennek bizonyulnak (Burgers-Vranken 2004). Így egyre nagyobb teret kap 
Földi Zsuzsa : A társadalmi részvétel szerepe a városfejlesztés gyakorlatában

- Európai és hazai tapasztalatok. - Tér és Társadalom 23. évf. 2009/3. 27-43. p.

Európa-szerte a közösségi, piaci és civil szereplök partnerségén alapuló új irányítási forma, a „governance”, mint a társadalmi részvétel háttérmechanizmusait megteremtő vezetési-irányítási keret. Az elemzők többsége egyetért abban, hogy - tekintetbe véve a globalizációt és társadalmunk növekvő összetettségét - többé lehetetlen, hogy az állam a szereplők és a közvetlen érintettek részvétele nélkül irányítson (Taylor 2007). Az új irányítási forma és a részvételen alapuló városfejlesztési gyakorlat az indusztriális város posztindusztriálissá, illetve a modern városi társadalom posztmodernné való átalakulásának folyamatában gyökeredzik. A városfejlesztés oldaláról tekintve Nyugat-Európában az 1980-as és részben az 1990-es években a városfejlesztés és a tervezés hangsúlya - érthető módon - a barnamezős területek újrahasznositására és a városközpontok fizikai megújítására esett. A városfejlódés ezen szakaszában megerősödött az állam (és az önkormányzatok) partnerségi viszonya a befektetőkkel és a fejlesztökkel. Ennek hátterében az állt, hogy a jóléti állam (,welfare state”) városfejlesztésben vállalt szerepe a beavatkozásokhoz szuikséges források hiánya miatt visszaszorult. Az átalakuló gazdasági struktúrában az új típusú partnerség külső, piaci források bevonását célozta (adó- és egyéb kedvezményeken keresztül), kevésbé volt fontos a társadalmi konszenzus és társadalmi részvétel, ami természetesen nem zárta ki annak formális meglétét. Európa nagyvárosaiban jellemzővé váltak a fizikai megújulást és funkcióváltást célzó és elsősorban közös üzleti és önkormányzati érdekeket szolgáló, speciális fejlesztési társaságok bevonásával végzett mega-projektek (irodaházak, üzleti negyedek, bevásárlóközpontok, multifunkcionális kereskedelmi-szolgáltató épületkomplexumok stb.), amelyek ugyan megújulást, esetenként dinamizmust eredményeztek, de a neoliberális gazdasági berendezkedésben gyökerező, fokozódó városi társadalmi problémákra nem adtak választ. Söt, mondhatjuk, hogy a beavatkozások gyakorlatilag megteremtették és erősítették a „társadalmi polarizáció infrastruktúráját”, sajátos tereket teremtve a polarizáció fizikai megjelenéséhez. A piaci szereplók számára kevésbé „érdekes” közösségi terek és lakóterületek megújítása jellemzően háttérbe szorult.

Kutatók és felelós EU-politikusok már a folyamat elején felismerték a jótékony állam visszahúzódásának a városi társadalmi és térbeli struktúrákban jelentkező kedvezötlen hatásait. Közösségi szinten (EU) az 1990-es évek közepétől kezdtek foglalkozni a különböző célú, súlyú és irányultságú városfejlesztési programokkal (lásd Barta Györgyi tanulmányát a folyóirat ezen számában). Látható, hogy az EU regionális politikájänak középpontjába egyre inkább a város került. 1994-töl sorban születtek az egyre konkrétabb közösségi célokat megfogalmazó nyilatkozatok, amelyek 2007ben a Lipcsei Chartában csúcsosodtak ki. A Charta felhívta a figyelmet a makroszintủ városfejlesztési koncepciók és a területrendezés terveinek szükséges összekapcsolására, városrészeinek és projekttérségeinek (akcióterületek) területi szintü komplex kezelésére, foglalkozott a központi irányítás és - ami jelen esetben központi kérdés - a helyi kezdeményezés szintjeinek kezelésével, vagyis a különböző területi és közösségi szintek közötti „,munkamegosztással” (és ezzel a társadalmi részvétellel).

$\mathrm{Az}$ „urban issue” a városi társadalmi konfliktusok felerősödésével (szegregáció, erősödő leszakadás, munkanélküliség, második generációs bevándorlók problémái) 
olyan komplex problémakört jelentett, amely hasonlóan komplex megoldásokért kiáltott és kiált. Felismerésre került, hogy a problémák egyoldalú kezelése csak fizikai beavatkozásokkal nem hoz hosszabb távon megoldást. A komplex problémákra adandó komplex válaszok túlléptek a mechanikus tervezés és építészeti problémamegoldás körén és jóval empatikusabb megközelítést igényeltek. Elötérbe került tehát az igény az integrált szemlélet érvényesítésére és olyan többszereplös megoldásokra, amelyekben a társadalom, mint a problémákat magában hordozó - rapoporti értelemben - nem kötött (rugalmasan változó) városi környezeti elem, maga is aktív szerepet vállal. Miközben - különösen az új piacgazdaságok nagyvárosaiban - az ezredforduló után továbbra is napirenden voltak az állam, az önkormányzatok és a fejlesztök „érdekszövetségéböl” adódó mega-projektek, egyre gyarapodtak a kisebb, föleg helyi közösségeket célzó fejlesztések is. Az EU városfejlesztési célú támogatási rendszerében is egyre erősebb hangsúlyt kapott a társadalmi elem.

Már közvetlenül az ezredfordulót követő években a városföldrajz nemzetközi szakirodalmában egyre nagyobb felületet kapott a ,global-local" dichotómia, tehát a globális és a helyi érdekek és szereplök egyidejú jelenlétének térbeli és társadalmi hatásának elemzése ${ }^{8}$, hangsúlyozva, hogy ez a kettősség egyértelmüen projektmérethez, célhoz és csoportérdekekhez kapcsolódóan, egyidejüleg kerül kifejeződésre a városi térben (Földi-Van Weesep 2007; Kempen 2007; Tasan Kok 2007; Tasan Kok-Van Weesep 2007). Jelenleg, a globális pénzügyi, gazdasági - és tegyük hozzá - társadalmi válság idején még inkább felértékelödőben vannak a közösségi, egyben lokális megoldások. Többek szerint áttörés zajlik a társadalmi részvétel szükségességét illetően.

Látható, hogy a társadalmi részvételről, a civil aktivitásról, így az alulról építkezésröl - nemcsak a szocializmusban, hanem a piacgazdaságban is - leszoktatott városi társadalmakban (pl. Magyarországon is) a döntésekben és a tervezésben való részvétel a környezet alakításában többnyire a fent említett mechanizmusok által irányítottan (1. ábra) zajlik, jellemzően hosszabb távú stratégia vagy következetesség nélkül, ad hoc jelleggel. Bizonyosan vitatkoznának (és tegyék is!) ezzel az általánosítással a jól szervezett „professzionális” érdekvédelmi szervezetek (akikkel cikkünk nem foglalkozik), illetve a lokális szinten müködő, többnyire egy-egy személyhez vagy kisebb csoporthoz kötődő aktív civil szervezetek. Talán a lokális szinten érdemes ténylegesen aktívnak lenni, és a nagy ívű, városi szintú, hosszabb távú stratégiákat érdemesebb a szakértőkre hagyni. Vagy mégsem? A kérdés erőteljes hangsúlyt kapott a 2008-ban nagy számban készülő Integrált Városfejlesztési Stratégiák esetében, amelyeket egyértelmủen a NFT2. ROP integrált funkcióbővítő városközpont-fejlesztést célzó pályázati konstrukciók hívtak életre. A témában (is) lefolytatott tervezői és önkormányzati tapasztalatokra vonatkozó interjúk alapján elmondható, hogy a városokban általános tendencia szerint a lakosság messze nem folyamatosan részese a várostervezésnek, bár tagadhatatlan tény, hogy a zavaros városfejlesztési és -tervezési gyakorlat az eddigiekben ezt nem is nagyon tette lehetővé, bár ebben a közeljövőben talán várható némi változás (a területfejlesztésről és rendezésrőll szóló kormányrendelettervezet tartalmaz már partnerségi terv készítési kötelezettséget). 
Földi Zsuzsa : A társadalmi részvétel szerepe a városfejlesztés gyakorlatában

- Európai és hazai tapasztalatok. - Tér és Társadalom 23. évf. 2009/3. 27-43. p.

$\mathrm{Az}$ a tény, hogy a társadalmi részvételnek növekvő jelentőséget tulajdonítunk, valóban a posztmodern vagy posztindusztriális kor eredménye, de mindenképpen olyan jelenségekhez kötődik, amelyek a globalizáció rész-, illetve ellenfolyamataiként értelmezhetők. Jól példázza ezt az alábbi, nem hazai forrásból származó idézet: „A városrészek megújulása a közösségek igényeinek megértésével kezdödik. A közösségeket szükséges meghallgatni és fontos velük kommunikálni, a leghatékonyabb beavatkozások gyakran azok, amelyek tervezésében, kivitelezésében, és ahol lehet, az irányitásában is a közösségek aktívan részt vesznek." (A New Commitment... 2001, 10)

Valójában több forrást áttekintve a hazai várostervezési (-fejlesztési, illetve -rendezési) politika csak közeledik a fentiek megfogalmazásához és gyakorlatban való alkalmazásához.

Az Integrált Városfejlesztési Stratégiák készítését (2007) tartalmilag és módszertanilag meghatározó tematika partnerségre vonatkozó része - nyilván a nemzetközi tapasztalatokra és EU-politikák elvárásaira alapozva - már közelít ehhez a szemlélethez. Az elvárásrendszer ugyanakkor híján van a területi tervezés területi szintjei közötti kapcsolatot végérvényesen tisztázó és a tervezésben játszott társadalmi részvétel rendszerét megszabó törvényi háttérnek, amely pl. Nagy-Britanniában 2004-ben letisztázott törvényi keretet kapott (lásd alább).

A várospolitika továbbra is nemzeti politika az EU-ban, ennek megfelelően a legváltozatosabb törvényi szabályozásokat és gyakorlatot találjuk a várostervezésre és a lakosság döntésekbe történő bevonására.

\section{A társadalmi részvétel formái, ideális területi szintje, hátrányai és szabályozottsága - nemzetközi és hazai tapasztalatok}

A várostervezés számos, nemzeti hagyományokból eredő aspektusa mellett olyan közös tervezési szempontok is felmerülnek az utóbbi évtizedben az EU országok várostervezési és -fejlesztési gyakorlatában, mint a partnerség és a közösségi részvétel kérdésköre. A téma egyre hangsúlyosabb megjelenése annak is köszönhető, hogy a participáció a városfejlesztést (rehabilitációt) célzó beavatkozások finanszírozásának előfeltétele, azaz az EU és a nemzeti forrásokhoz történő hozzáférést befolyásoló tényezó lett. Valós jelentősége, gyakorlatban történő megvalósítása és annak hatékonysága a tapasztalatok szerint országonként (kultúránként) erősen változó.

Természetszerüleg az európai gyakorlat országonként eltér, és nagyban függ a területi és településtervezési rendszer jellegétől, valamint a társadalmi részvétel szabályozottságától. A részvétel bizonyos könnyen elérhető és jó érdekérvényesítő képességgel rendelkező társadalmi (és/vagy érdek-) csoportokra és bevett formákra szorítkozik, így többnyire formális marad (pl. Olaszország); vagy másik „szélsőségként" valamilyen írásban is rögzített szabályozott formát ölt, és tudatosan figyelmet fordít a társadalmi részvétel rejtett aspektusaira, hatékonysága meghatározott indikátorok mentén monitoringozásra kerül (pl. Nagy-Britannia). 
Földi Zsuzsa : A társadalmi részvétel szerepe a városfejlesztés gyakorlatában

- Európai és hazai tapasztalatok. - Tér és Társadalom 23. évf. 2009/3. 27-43. p.

TÉT XXIII. évf. 2009 『 3

A társadalmi részvétel szerepe...

Burgers és Vranken $(2004,51)$ kilenc európai ország Városfejlesztési Programokkal (Urban Development Programmes, UDP) kapcsolatos tapasztalatainak szintéziseként a részvétel különféle szintjeire (mélységére) egy létra fokainak hasonlatát használják. A városfejlesztési program itt nem feltétlenül egy egész városra, hanem akár egy-egy beavatkozási területre is vonatkozhat.

- A létra legalsó, legszélesebb fokán a lakosság információval történő ellátása áll a Városfejlesztési Program állásáról, ami ugyan előfeltétele a társadalmi részvételnek, de önmagában nem tekinthető annak;

- a középső létrafokokon egy olyan konzultációs folyamat áll, amelynek keretében a lakosok elmondhatják kritikai észrevételeiket, véleményüket, de a döntéshozatalba nincs beleszólásuk, az teljes mértékben az önkormányzat kezében marad;

- a legfelső fokokon olyan részvételi formák szerepelnek, mint az „együttes döntés”, „partnerség”, „delegált erő”, „lakossági kontroll”. Ezen a szinten tehát a lakosság részt vesz a végső döntéshozatali folyamatban is, és valóban irányíthatja a végső kimenetet.

Ennek fényében a szerzők kijelentik, hogy részvételről beszélni csak a harmadik esetben érdemes, hiszen a részvétel az „erőviszonyok újrarendezésének” egy formáját jelenti. Ugyanakkor nem lehet felugrani a legfelső fokra, ez egy olyan folyamat, amelyben mindig szükség van a legalsó fokra is.

A létra-hasonlat a társadalmi részvétel európai gyakorlata evolúciójának is megfeleltethetö, mivel egyfajta idöbeliséget is tükröz a részvétel gyakorlatának fejlődésében. Természetesen nem minden európai országban és városban jutottak el a létra legfelső fokára, és azt sem állíthatjuk, hogy Magyarországon a városfejlesztési akciók kapcsán csak és kizárólag az elsô szint (vagy az sem) él. Tény azonban, hogy mivel a társadalmi részvétel formái és tartalmi keretei nincsenek szabályozva (az IVS-tematika vonatkozó részében sem szabályozták, csak ajánlások kerültek megfogalmazásra), a tervezö önkormányzatokon - így sokszor hosszabb távú politikai megfontolásokon vagy pályázati kötelezettségeken - múlik, hogy meddig „,másznak fel a létrán”.

Nemzetközi vizsgálatunkban egy német tervező cég 1980 óta a tervezésben dolgozó szakértője is ủgy ítélte meg, hogy ,, a lakosságot általában csak informálják, a tartalmi kérdésekbe szinte egyáltalán nem szólhatnak bele". Írja ezt annak ellenére, hogy a németországi tervezésben aktívan törekednek arra, hogy sokféle módszerrel a lehető legtöbb helyi szereplöt bevonják a folyamatba.

A nemzetközi gyakorlat szerint a városrészek szintjén a tervezésben és a fejlesztésben létező partnerség ,adok-kapok” viszonyként is értelmezhetö:

- Információszerzés a lakosságtól (ez a forma értelmét veszti, sőt a hatékonyság ellen hat, amint az önkormányzat minden szükséges információt beszerzett a lakossági szükségletekről).

- A lakosság oktatása, felkészítése a várospolitikával kapcsolatban, aminek az a veszélye, hogy a lakosság készen kapja, hogy mit is kell gondolnia egyes problémákról és azok megoldásáról. A probléma megoldható úgy, hogy 
Földi Zsuzsa : A társadalmi részvétel szerepe a városfejlesztés gyakorlatában

- Európai és hazai tapasztalatok. - Tér és Társadalom 23. évf. 2009/3. 27-43. p.

például a stratégiaalkotásra létrehozott tematikus munkacsoportokban biztosítják, hogy a döntési funkcióval rendelkező szereplök (várospolitika, önkormányzat) kisebbségben legyenek. Ezáltal még a gyanúja sem merülhet fel annak, hogy elöre kitalált gondolatokhoz/eredményekhez keresik a lakosság formális egyetértését (Funke 2008).

- A lakosság „hatalommal történő felruházása”, bevonása a döntéshozatalba. Ez a szociális városrehabilitációs beavatkozási területek kapcsán nyerhet valódi jelentőséget, mivel itt él alacsony érdekérvényesítő képességgel rendelkező, „nehezen elérhető" lakosság. Mégis ezzel kapcsolatban jegyzik meg Mathers és szerzőtársai (2008), hogy pl. a brit kormányzat, mindenre választ adó új eszköze „A részvétel”, a saját értelmezésében figyelmen kívül hagyja, hogy ezek a társadalmi csoportok miként értelmezik a participációt - a külső erőfeszítés ellenére egyre többen tudatosan élnek a nem részvétel jogával.

A társadalmi részvétel kérdésköre (a nemzetközi gyakorlatban is) helyi szinten legtöbb esetben a rehabilitációra (integrált fejlesztésre) kijelölt városi területekre koncentrálódik. Ez ugyanis az a területi szint, amelyen a nyugat-európai tervezők hatékonynak gondolják a társadalmi részvétel bizonyos (lakossági) formáit. Ezt alátámasztják a tervezés nemzetközi gyakorlatának megismerését célzó kérdoíves felmérés információi. Egy olasz tervező partner a szomszédsági (,neighbourhood”) szintet jelölte meg hatékonyabb kommunikációs szintnek, amit meg is indokolt:

„,... ez tünik normális esetben a részvétel megfelelö (racionális) szintjének, míg a városi szint túl nagy és átláthatatlan. " (olasz válaszadó)

Egy németországi tervező véleménye szerint azért ez a részvétel ideális szintje „....mert a problémák, tervek és projektek ezen a szinten konkrétak, a városi szinten a tervezési tartalom legtöbbször túl általános és emelkedett. Véleményem szerint a társadalmi részvétel a városrészi szinten igér több sikert. A szükebb környezettel való szorosabb kapcsolat miatt a részvételi akciók gyakrabban adnak konkrét eredményeket. A városi szinten is van azonban elönye, de itt a különbözö csoportok (ipar, kereskedelem, szolgáltatások) erösebben próbálják érdekeiket érvényesiteni." (tervezö cég Németországból)

Egyéb források is a városi mikroszintet (lakóterületek, ill. -közösségek) tartják a társadalmi részvétel leghatékonyabb szintjének. Itt valósulhat meg igazán hatékonyan az integrált fejlesztések egyik fö elvi alaptétele, az, hogy a fejlesztéseket nagy részben alulról jövő (bottom-up) kezdeményezésekre szükséges építeni. Dániában egész lakónegyedek tervezése folyik ilyen szemléletben, ugyanakkor ezek finanszírozására komoly kormányzati programok és források állnak rendelkezésre ${ }^{10}$.

A témával kapcsolatban mindenképpen felvetódik a különféle területi szintek és speciális tervezési területek (pl. úthálózat-fejlesztés) kidolgozásában való társadalmi részvétel formáinak, mélységének kérdése. Nagy-Britanniában, ahol a városi szintủ tervezési dokumentumok készítésének alapfeltétele a társadalmi részvétel, különbséget tesznek területi szintek szerint és tervtípusonként, hogy milyen szereplöket milyen formában vonnak be a folyamatba. A speciális szakterületekre vonatkozó 
tervdokumentumok esetében a hangsúly nyilvánvalóan eltolódik a professzionális szervezetek és partnerszervezetek felé.

A több ország tapasztalataira épülő vizsgálatok alapján felvetődik a társadalmi részvétel számos negatív aspektusa is (Burgers-Vranken 2004):

- Bizonyos társadalmi csoportok jóval felkészülttebbek és erőszakosabbak, érdekvényesítő képességük jóval erősebb, mint a kevésbé képzett csoportoké. Az ,elitizmus" nevezhetô a közösségi részvétel egyik csapdájának.

- Előfordul, hogy bizonyos egyének vagy csoportok úgy tesznek, mintha az egész közösség érdekében szólnának, miközben igyekeznek bizonyos csoportokat és érdekeket szándékosan kizárni a kommunikációból.

- A részvétel jelentősége más és más a politikusok, a tervezők és a lakosság számára. Az alacsony érdeklődés és részvétel félrevezetỏ annak, akinek ez a napi feladata, míg a lakosságnak - föleg ha közvetlenül nem is érinti a problémamegoldás bemutatott módja - egy időtöltési lehetőség.

- Probléma, hogy a részvételt sokan (elsősorban a városvezetés és a politikusok) még mindig ajándékként értelmezik, miközben az egy jog. A részvétel lehetöségét minél közelebb kell vinni a résztvevőkhöz, tehát egyes esetekben eléjük kell menni a lehetőséggel.

A negatív aspektusok elkerülésének hatékony módja, ha egy-egy város a társadalmi részvétel kereteit és feltételrendszerét annak tervezésén keresztül konkrétan meghatározza (ez Magyarországon pl. a városmarketing tervvel ellentétben még nem jellemző gyakorlat, és semmiféle formális kötelezettség nem létezik erre vonatkozóan). Példaként említhetö, hogy Nagy-Britanniában a 2004-ben elindított új területi tervezési rendszer egyik legfontosabb újítása, hogy a tervezési csomag (Local Development Framework) kötelező elemeként ír elő egy olyan dokumentumot, amely az önkormányzatok számára a tervezésben történö társadalmi részvétel paramétereit rögzíti. Ez értelmezhető egyfajta speciális kommunikációs tervként is, de azt tartalmában jóval meghaladja. Ennek megfelelően az új helyi (local) tervezési rendszer egyik fó alkotó eleme az ún. Statement of Community Involvement (társadalmi részvételről szóló nyilatkozat). Ennek feladata rögzíteni, hogy a tervezésért felelős szervek a tervek készítése során hogyan és mikor kívánnak konzultálni a helyi lakossággal és az egyéb érintettekkel. A dokumentum célja, hogy a konzultáció a tervek készítésének kezdeti szakaszában és annak is lehető legkorábbi idöpontjában megkezdódjék, annak érdekében, hogy a helyi közösség minél szélesebb lehetőséget kapjon a részvételre a tervkészítésben, és ezzel - a terveken keresztül érvényesítse elvárásait. Minden kommunikációs dokumentum a helyi sajátosságoknak megfelelően készül, de mindegyikkel szemben elvárás, hogy tartalmazza:

- Miben számít az önkormányzat a közösségi részvételre (azon tervdokumentumok listája, amelyek esetében a konzultáció megvalósul);

- A hivatal mikor és hogyan keresi a kapcsolatot a közösséggel (részvétel lehetséges formái, az információszerzés és -adás módjai, a politikák és tervek alakításának folyamata és az alkalmazott visszacsatolási technikák); 
Földi Zsuzsa : A társadalmi részvétel szerepe a városfejlesztés gyakorlatában

- Európai és hazai tapasztalatok. - Tér és Társadalom 23. évf. 2009/3. 27-43. p.

- Kinek a részvételére számít (a társadalom legszélesebb rétegei, föként azon nehezen elérhető csoportok, akik normál esetben nem vesznek részt a tervezésben).

A brit eset a társadalmi részvétel szabályozásának egy viszonylag szélsőséges módját jelenti, amelyben törvényileg elöirt a folyamat kereteinek meghatározása. Ezzel szemben Olaszországban helyi szinten (városrész és város) koordinált a társadalmi részvétel. Számos olasz városban találunk a társadalmasításért felelős önkormányzati megbízottat (,City Council Deputy to Participation”), de ez az ,intézmény” nem kötelezö, hanem válaszható megoldás. Tehát valós törvényi szabályozás nincs.

Németországban a társadalmi részvételt városi szinten koordinálják, az esetek többségében a városfejlesztéshez kapcsolódó tervezési feladatokat maga a település szervezi és bonyolítja le, nem a tervezési dokumentum elkészítésébe bevont tervező cég (ahogy az Magyarországon tapasztalataink szerint jellemző). Participációs terveket vagy stratégiákat nem készítenek, ám építenek a társadalmi részvétel szervezésében nyert korábbi tapasztalataikra, amelyre egy német városi szakértỏ a következőképp utalt:

„A lakosság részvétele az itt emlitett tervezési folyamatban [IVS] a korábbi akcióinkon, rendezvényeinken alapult, amelyek egyrészt a városi szintre, másrészt szükebben a belvárosra vonatkoztak. Így nézve létezik a társadalmi részvételnek egyfajta folyamatossága, amelyböl fontos tartalmi megállapitások vonhatók le. Mindazonáltal ezt kevésbé nevezném alaposan megtervezett participációs stratégiának."

A hazai gyakorlat a társadalmi részvétel folyamatát többnyire a helyi társadalomra, a civil szervezetekre és vállalkozók csoportjaira koncentrálja, kevésbé terjeszti ki a partnerszervezetekre, nem beszélve a nehezen megközelíthető csoportokról. Korábbi városfejlesztést célzó pályázati programokban (pl. URBAN) elvárás volt a társadalmi egyetértés, a véleménynyilvánítás rögzítése és azok beépitése a rekonstrukciós elképzelésekbe. Az Integrált Városfejlesztési Stratégia volt az első olyan városi szintü átfogó tervezési dokumentum, ahol „kötelezően” elóírt elem volt az ún. társadalmasítás, azaz a társadalmi részvétel a forrásszerzés (pályázati dokumentáció) formális feltételévé is vált.

$\mathrm{Az}$ áttekintett IVS-ek ( $32 \mathrm{db}$ ) eltérő súllyal értékelték a részvétel jelentőségét, és ennek megfelelően a legváltozatosabb terjedelemben és eszközrendszerrel hajtották végre a feladatot. Volt, ahol érvényesült az elitizmus - azaz mind az IVS, mind a kapcsolódó Akcióterületi terv esetében csak a vezetô civil szervezetek és az intézményvezetők kerültek bevonásra, a kész dokumentumok pedig - a formalitásnak eleget téve - végleges dokumentációként kerültek fel a város honlapjára, tájékoztatva a lakosságot a tervezési folyamat végeredményéröl.

Néhány esetben viszont - lássuk be ezek voltak kevesebben -, a városi és városrészi szintű fejlesztési elképzelések azelőtt kerültek rögzítésre, mielött bárki egy szakértői ajánló sort leírt volna. Folyamatosan zajlott a konzultáció a tervezés különféle (előkészítő, munkaközi és végső) fázisaiban. A legnagyobb hangsúlyt az első és harmadik szakasz kapta. 
Földi Zsuzsa : A társadalmi részvétel szerepe a városfejlesztés gyakorlatában

- Európai és hazai tapasztalatok. - Tér és Társadalom 23. évf. 2009/3. 27-43. p.

Az IVS (2007) eszközrendszerében a partnerségi fejezetre vonatkozó tematika nem nyújtott elegendő segítséget abban, hogy a települések hogyan definiálhatják a társadalmasítás során bevonandó célcsoportjaikat, milyen lehetséges egyeztetési, részvételi formákat érvényesíthetnek, és azokat miként időzithetik. A társadalmi részvétel hatékonysága azért is maradt viszonylag szerény, mert sokan, sokféle fórumon részt vettek már, de talán nem érezték, hogy lett volna értelme, azaz nem tudták követni, hogy javaslataik milyen formában épültek be a dokumentumokba. A kommunikáció és konzultáció többnyire kapkodva, a tervezési folyamat végén történt. Az IVS-ek kapcsán végzett tervezői, szakértői interjúk és a személyes tapasztalatok esszenciája a következő kérdésekben fogalmazódik meg:

- Miért várjuk el kétségbeesetten forrásokért kapkodó városainktól - függetlenül azok méretétől és apparátusuk szakmai felkészültségétől -, hogy források, tapasztalat hỉján olyan professzionalizmussal és eredményességgel hajtsák végre gyakran elsö ízben (!) terveik társadalmasítását, mint nyugati kollégáik?

- Miért gondoljuk, hogy a helyi társadalom (definíció szerint) azonnal tudja, hogy mit is kezdjen egy szakmai zsargonnal teletüzdelt fejlesztési stratégiával; és gyakran miért jegyezzük meg kritikával - amikor a tervezők stilisztikai impotenciáját észrevételezik, vagy legjobb esetben a helyzetértékelésben adatokat pontosítanak -, hogy: Többre nem futotta?

- Miért jegyezzük meg, hogy a társadalom éretlen az érdemi részvételre, miközben ez egyrészt nem igaz, csak eddig nem nagyon kérdezte meg őket senki, és nem törekedtek felkészítésükre sem; másrészt maguk az önkormányzati hivatali dolgozók sem értik, hogy mi zajlik körülöttük. (Ennek oka sok esetben a futószalagon készített pályázatok miatti túlterheltség, azok koordinálatlansága az önkormányzati hivatalok osztályai és tevékenységei között.)

Lényeges lenne a társadalmi részvétel - nemzetközi gyakorlattal alátámasztott programszerü ütemezése és szisztematikus, egész tervezési spektrumot magában foglaló kiépítése, az érintettek felkészítése. A problémakör tehát jóval messzebbre visz, mint a számos egyeztetés és átdolgozás után továbbra is városrehabilitációs háttéranyagként tekintett IVS és az Akcióterületi tervek készítésében való társadalmi részvétel megléte vagy mibenléte. A területi tervezés szintjeinek összekapcsolása, monitoringozása, a szereplők egyes szintekhez kötődô kompetenciáinak tisztázása még mindig hiányzik ahhoz, hogy e látszólag partikuláris kérdéskör valamelyest átláthatóbb kereteket öltsön - véletlenül sem túlszabályozott formában (!).

A kritikai realista modellbe (1. ábra) visszahelyezve a problémát: A hazai gyakorlatban a törvényi keretek, illetve a nemzetközi gyakorlat széles körü ismertségének hiányában (ami a nyílt rendszerre gyakorolt külső hatásokat jelentené) a helyi önkormányzatok, mint a városfejlesztést irányító mechanizmusok nem kapnak olyan impulzusokat, amelyeken keresztül felelősnek, illetve kötelesnek éreznék a helyi közösségek szisztematikus bevonását a város(rész)fejlesztéssel kapcsolatos tervezési folyamatba, illetve az azokkal kapcsolatos döntésekbe. Nem csak a mechanizmusokra gyakorolt külső hatás gyenge, hanem sokszor a helyi társadalom sincs tisztában azzal, 
Földi Zsuzsa : A társadalmi részvétel szerepe a városfejlesztés gyakorlatában

- Európai és hazai tapasztalatok. - Tér és Társadalom 23. évf. 2009/3. 27-43. p.

hogy mi történik körülötte - mihez van, illetve lehetne joga. Ennek következtében az a helyzet alakulhat ki, hogy a mechanizmusok kötött környezeti elemekre gyakorolt hatása a meghatározó (források, pályázatok menedzselése). A külső hatások irányító (orientáló) szerepe nélkül a helyi társadalom bevonása esetleges. Így egyszerúen nem csak elhalványodik az említett hajdani organikusabb viszony ember és városi környezete között, hanem esetlegessé válik, illetve többnyire ki sem alakul az 1. ábrán jelzett módon a helyi társadalom közvetett (formális) bevonása (ez alól kivétel a pályázati „kötelező” társadalmasítási folyamat).

A hazai és EU-s gyakorlati példákra alkalmazott realista modell rávilágít arra, hogy mely viszonyrendszereken volna szükséges módosítani a rendszerben annak érdekében, hogy az épített környezet és a helyi társadalom közötti kapcsolat jellege normalizálódjon, akár az IVS-ek és Akcióterületi tervek tartalmát, akár a projektszintủ beavatkozások végrehajtását nézzük. Nem állítható, hogy ezzel választ adtunk a kritikai kérdésünkre: „Hogyan kéne lennie?”, de talán elemzésünkkel és esettanulmányainkkal felkeltettük az érdeklődést a téma iránt a „politikacsinálók” és gyakorlati szakemberek körében egyaránt.

\section{Összefoglalás}

Cikkünk kritikai realista keretbe foglalva olyan témát feszeget, amely Európaszerte egyre jelentősebb hangsúlyt kap a (nagy)városi problémák komplexitása és új megoldási stratégiák szükségessége miatt. Az európai (főleg nyugat-európai) városfejlesztés gyakorlatában egyre nagyobb hangsúlyt kap a tervezést és a kapcsolódó döntéseket érintő társadalmi részvétel, amely a hazai pályán elsősorban az EU-s pályázati források eléréséhez szükséges feltételrendszer részét képezi és nem természetes része a városfejlesztési dokumentumok és konkrét városfejlesztést célzó projektek tervezésének és végrehajtásának.

A realista absztrakció módszerével feltárjuk a város(rész) szereplőinek dinamikus kapcsolatrendszerét, bemutatva, hogyan halványodott el környezet és társadalom kapcsolata és e kapcsolat miként teremtődik (vagy nem teremtődik) újjá közvetett, felülrỏl szervezett társadalmi részvétel formájában. A cikk feltárja azokat az okokat és folyamatokat, amelyek világszerte a felülröl szervezett társadalmi részvétel szükségességéhez vezettek (globalizáció, többszereplös megoldásokat kívánó komplex városi, fizikai és társadalmi problémák). Néhány európai esettanulmánnyal bemutatásra kerül, hogy e tekintetben is mennyire diverzifikált az európai városállomány, és az EU-s direktívákon túl milyen mértékben múlik a nemzeti politikákon és demokratikus hagyományokon a társadalmi részvétel fontossága. Nemzetközi szakértői interjúk alapján bemutatásra kerül, hogy a lokális, azaz városrészi (akcióterületi) szint a legalkalmasabb a társadalom bevonására, a városi és városrégiók szintje már túl absztrakt és megfoghatatlan annak komplexitása miatt.

A hazai IVS-ek kapcsán tapasztalt társadalmasítási gyakorlat nyomán végül rávilágítunk néhány szereplők közötti relációra, ami a továbbiakban beavatkozást igényel 
annak érdekében, hogy a társadalmi részvétel a városfejlesztés gyakorlatában ne „letudandó" szükséges feladat, hanem a tervezés és a megvalósítás magától értetődő részévé váljon. Ezzel igyekszünk a kritikai tudományfilozófiai irány „Milyennek kéne lennie? alapkérdésére a konkrét problémakörön túlmutató válaszlehetöséget bemutatni.

\section{Jegyzetek}

1 A viszonyrendszer kritikai realista módszertani eszközzel (absztrakció) történő feltárásával a szerző Neighourhood Dynamics in Inner-Budapest c. (2006) az Utrechti Egyetem által angol nyelven publikált doktori értekezésében részletesen foglalkozik.

${ }^{2}$ A hazai tapasztalatokat az MTA RKK Budapesti Osztálya által, a Nemzeti Fejlesztési és Gazdasági Minisztérium megbizásából végzett kutatás tárta fel, elsősorban az Integrált Városfejlesztési Stratégiák készítésének tapasztalatain keresztül.

${ }^{3}$ Panelli a társadalomföldrajzban használatos fóbb tudományfilozófiai irányzatokat a jelenségek vizsgálatát megalapozó kérdések mentén (is) elválasztja, amelyek a pozitivista, empirikus irányzatokban: $M i$ ez?; a humanisztikus (posztmodern) irányzatokban: Mit jelent?; a radikális és kritikai irányzatokban (amelyben cikkünk íródott): Milyennek kéne lennie? (Panelli 2004, 18)

4 Ellentétben a „labortisztaságú" pozitivista vizsgálati keretekkel.

${ }^{5}$ Ez a városfejlódésben annyit jelent, hogy hasonló társadalmi összetételü lakosság, hasonló épített környezeti beágyazódással egészen más fejlödési pályát futott be 1989 óta a különféle önkormányzati politikák és piaci szándékok hatása következtében.

6 A Nagymezó utcai mélygarázs története 2000 és 2007 között zajlott, és végül, részben a helyi lakosság és civil szervezetek kezdeményezésére (az építési engedély a lakók bevonása [értesítése!] nélkül került kiadásra 2005-ben) hosszas jogi procedúra után befejezódik (http://www.vedegylet.hu/ jonek6/data/II.1.m3.htm.). Vitatott kérdés, hogy az eljárás jogosságán túl a beruházás valójában nem enyhített volna-e a terület elviselhetetlen parkolási nehézségein, amennyiben a tervezés, pályáztatás és kivitelezés elókészitése az érintett lakosság és a civil szervezetek bevonásával történik.

${ }^{7}$ 2005. december 9. Kötelező politikává tenné a városi dimenziót a regionális biztos: „A párizsi gettólázadás ráirányította a figyelmet, hogy a strukturális politikán belul külön hangsúlyt kell adni a városi dimenziónak - jelentette ki Danuta Hübner egy ma megrendezett konferencián." (http://www.mno.hu/ portal/324109)

8 A The Netherlands Journal of Housing and the Built Environment 2007/22. tematikus száma teljes egészében ezzel a témakörrel foglalkozik.

9 Ez a törekvés már a kormány 2003-as Fenntartható közösségekre vonatkozó tervében (Sustainable Communities Plan) is tükröződött, amely elörevetíti a fenntartható közösségek vízióját, és különösen fontosnak ítéli a hatékony közösségi részvételt.

${ }^{10}$ Dánia (Kvarterplan - városnegyed terv) - a lakosok tervezik a lakónegyedet. A program végrehajtása mindenütt egy integrált lakónegyed-fejlesztési terv kidolgozásával kezdődik. A helyi projekttitkárság kezdeményezi a folyamatot azzal, hogy nyílt meghallgatásokat szervez. A felvetett témákkal kapcsolatban bizottságok dolgoznak ki projektet és mérlegelik a javaslatokat. Így a tervezési stádiumban megtörténik a lakosok és a helyi irányító csoport bevonása a helyi önkormányzati hivatal osztályaival történő folyamatos párbeszédbe. Minden városnegyed fejlesztési terve konkrét javaslatokat tartalmaz intézkedésekre és projektekre vonatkozóan, és részletesen elemzi a szuikséges bevonandó forrásokat. A tervet (Kvarterplan) a városi tanács vitatja meg és fogadja el, végül a városnegyed és a városi önkormányzat között egy szerzödés születik. A Kvarterplant a központi kormányzat jóváhagyja, és minden évben ellenơrzi annak megvalósulását az önkormányzat által készített előrehaladási jelentés alapján. 
Földi Zsuzsa : A társadalmi részvétel szerepe a városfejlesztés gyakorlatában

- Európai és hazai tapasztalatok. - Tér és Társadalom 23. évf. 2009/3. 27-43. p.

\section{Irodalom}

A New Commitment to Neighbourhood Renewal National Strategy Action Plan. Report by the Social Exclusion Unit. (2001) Cabiet Office, London.

Barta Gy. témavezető (2008) Javaslatok az Integrált Városfejlesztési Stratégiák készitését segitő Kézikönyv módositására hazai IVS-ek elemzése és külfóldi tapasztalatok alapján. Zárótanulmány. MTA RKK KÉTI Budapesti Osztálya, Budapest.

Burgers, J.-Vranken, J. (eds.) (2004.) How To Make A Successful Urban Development Programme. Experiences From Nine European Countries. UGIS Collection 3: Garant, Antwerpen/Appeldoorn.

Földi, Zs. (2006) Neighbourhood Dynamics in Inner-Budapest - a realist approac. NGS 350. Netherlands Geographical Studies, Utrecht.

Földi, Zs. -Van Weesep, J. (2007) Impacts of globalisation at the neighbourhood level in Budapest. - The Netherlands Journal of Housing and the Built Environment. 22. 33--50. o.

Funke, U. (2008) Die Stadtleitbild-Entwicklung. Instrumente zur Stärkung zentraler Kernbereiche. Hessisches Ministerium für Wirtschaft, Verkehr und Landesentwicklung, Frankfurt am Main.

The Handy Guide to Planning. Urban Forum's Handy Guide to Englands Planning System produced with assistance of Planning Aid. Royal Town Planning Institute - Urban Forum, London.

Integrated Urban Development - a Prerequisite for Urban Sustainability in Europe. Background Study on the "Leipzig Charter on Sustainable European cities” of the German EU Council Presidency, Berlin.

Jones, P.-Evans, J. (2008) Urban Regenaration in the UK. SAGE Publication, London.

Joseph, J. (1998) In defence of critical realism. - Capital and Class. 65. 73-107. o.

Kempen, R. van (2007) Divided Cities in the 21 st century: challenging the importance of globalisation. The Netherlands Journal of Housing and the Built Environment. 22. 13-31. o.

Local Development Scheme 2007-2011. Manchester City Council, Manchester.

Mathers, J.-Parry, J.-Jones, S. (2008) Exploring resident (Non)-participation in the UK New Deal for Communities Regeneration Programme. - Urban Studies. 3. 591-606. o.

Panelli, R. (2004) Social Geographies - From Difference to Action. Sage Publications, London.

Rapoport, A. (1982) The meaning of the built environment: a non-verban communication approach. Sage, Beverly Hills.

Tasan Kok, T. (2007) Global urban forms and local strategies of property market actors. - The Netherlands Joumal of Housing and the Built Environment. 22. 69-90. o.

Tasan Kok, T.-Van Weesep, J. (2007) Global-local interaction and its impact on the cities. - The Netherlands Journal of Housing and the Built Environment. 22. 1-11. o.

Taylor, M. (2007) Community Participation in the Real World: Opportunities and Pitfalls in New Governance Spaces. - Urban Studies. 2. 297-317. o.

Városrehabilitáció 2007-2013-ban. Kézikönyv a városok számára. (2007) Önkormányzati és Területfejlesztési Minisztérium, Budapest. 


\title{
THE ROLE OF COMMUNITY INVOLVEMENT IN URBAN PLANING - THE EUROPEAN AND THE NATIONAL EXPERIENCE
}

\begin{abstract}
ZSUZSA FÖLDI
The study gives an explanation of the increasing importance of community involvement in the practice of urban planning and regeneration in Europe and in Hungary. To define the problem field the study uses a critical realist model and analyses the man-environment relation in the urban space. By abstracting the dynamism of urban space the model highlights the changes relative to the former organic relationship of people and their built environment and points out the ways it is re-established in a top-down manner by the mechanisms. The paper also provides examples for the regulation, general practice, success and failure of community involvement and participation.

The paper calls the attention to the weak interactions and activities of the mechanisms (influencing man-environment relations), which could be improved the make community participation more efficient and to the benefit of all in the future of urban spaces.
\end{abstract}

